\title{
Research on the teaching mode of "theory virtual equipment combat" in the aircraft spares seal up for safekeeping technology course
}

\author{
GUO Feng ${ }^{1, a *}$, SUN Weiqi ${ }^{2}$, ZHOU Bin ${ }^{3}$, ZHOU Wei $^{4}$ \\ ${ }^{1}$ Qingdao Campus, Naval Aviation University, Qingdao, China \\ ${ }^{2}$ Qingdao Campus, Naval Aviation University, Qingdao, China \\ ${ }^{3}$ Qingdao Campus, Naval Aviation University, Qingdao, China \\ ${ }^{4}$ Qingdao Campus, Naval Aviation University, Qingdao, China
}

\begin{abstract}
The practical teaching is an important link to improve the actual combat ability. Colleges and universities should attach importance to the practical teaching under the condition of actual combat, take more systematic and effective measures to improve the quality of practical teaching, and then comprehensively enhance the actual combat ability of the army. Through the organic integration of theory, virtual reality, equipment practice and actual combat, this paper deeply studies and considers the practical teaching environment, teaching material system, teaching staff, teaching material system, teaching quality evaluation methods and other issues in line with the actual combat of the army, so as to further promote the practical teaching level of aircraft spares seal up for safekeeping technology course.
\end{abstract}

\section{Introduction}

Aircraft spares seal up for safekeeping technology course is a highly technical professional course for aircraft spares management major. The original teaching mode is to light theoretical teaching and attach importance to practical teaching. Students only know how to operate, but don't know why, so there is a serious imbalance between knowledge and practice. Knowing the theory but not the practical ability is a typical example of having high vision and low hand, knowing but not being able to do, actually not knowing; knowing how to operate, but not knowing the reason, being able to do without knowing, is actually not doing. These two situations are lack for the cultivation of students' post ability, and the latter is the main problem faced by aviation material storage course. Doing without knowing will lead to the difficulty in achieving the training objectives of the post, affecting the improvement of teaching quality and the cultivation of applied and skilled talents, resulting in the students can not meet the requirements of the post.

In order to enable students to fully understand and master the knowledge of aircraft spares seal up for safekeeping technology course, make the practice teaching of aircraft spares seal up for safekeeping technology course closer to the needs of actual combat, we comply with the requirements of post education reform, explored the innovation of practice teaching mode, and put forward the practice teaching mode of "theory virtual equipment combat" integration, as in [1]. The mode is the deepening and expansion of the teaching mode of "integration of theory and practice". By using virtual information technology, combined with the characteristics of aircraft spares seal up for safekeeping technology course facing the battlefield, the seamless connection between theory, virtual, practice and actual combat is realized. The teaching mode has a very important theoretical and practical significance to promote the improvement of teaching quality and the cultivation of students' post ability.

\section{The overview of the integrated teaching mode of "theory virtual equipment combat"}

In the traditional teaching mode, theory course and practice course are isolated from each other and cannot realize the unity of teaching, learning and doing. "theory virtual equipment combat" teaching mode is not a simple combination of theory teaching and practice teaching in form, but starting from the cognitive law of students' skills and skills, realizing the organic combination of theory and practice, and effectively solving the problem of disconnection between theory and practice. The teaching mode of "theory virtual equipment combat" attempts to break through the traditional teaching mode of "basic course to specialized basic course to specialized course to skill training" and "discipline" and "systematization" in equipment teaching in theory and practice. The teaching of theoretical knowledge is based on the principle of "necessity and sufficiency", emphasizing "practicality and moderation", while skill training emphasizes science, standardization and creativity New capabilities, as in [2].

a*Corresponding author: gf536149@163.com 
In terms of teaching methods, skills training is taken as the center, and relevant theoretical knowledge is prepared to form a teaching module, and a teacher is responsible for both theoretical teaching and practice guidance, so as to ensure the synchronization of the two. Theory guides practice, and practical operation deepens the understanding of theoretical knowledge and makes the mastery of knowledge and skills more firm. The teaching link of "theory virtual equipment combat" is relatively concentrated, breaking the boundaries of theoretical courses, experimental courses and practical training courses, and integrating the theoretical teaching, practical teaching, military support and technical services of a certain course. It emphasizes giving full play to the leading role of teachers, by setting teaching tasks and teaching objectives, teachers and students can teach, learn, do and practice, constructing the framework of quality and skill training in the whole process, enriching the links of classroom teaching and practical teaching, and improving the teaching quality.

\section{The necessity of the innovation of "theory virtual equipment combat" integrated teaching mode of aircraft spares seal up for safekeeping technology course}

The theory course and practice course of traditional teaching of aircraft spares seal up for safekeeping technology course are independent of each other. Generally, on the basis of theory teaching in the classroom, the practical operation is carried out in the practice room. This teaching method leads to the serious disconnection between learning and doing, which is not conducive for students to understand theoretical knowledge and timely practise. It also brings great difficulties to the teachers. The teaching of theoretical courses is obscure and difficult to understand, which can not arouse the interest of students. The simulation software, which has spent a lot of energy to do, is also superficial at the end of the paper; when carrying out practical teaching, due to the limitation of teaching place conditions, it is unable to expand and sublimate the content of theory course by combining the content of principles and other contents. For a long time, this teaching mode has seriously restricted the improvement of aircraft spares seal up for safekeeping technology course teaching quality. "theory virtual equipment combat" achieves the five types of integration as shown in table I, so that students can integrate theory and practice according to the subject and learning requirements determined by teachers, as in [3].

Table1. The integration types of theory virtual equipment combat teaching mode

\begin{tabular}{|l|l|}
\hline $\begin{array}{c}\text { The indexes of } \\
\text { integration }\end{array}$ & \multicolumn{1}{c|}{ The types of integration } \\
\hline The first integration & $\begin{array}{l}\text { The integration of theory classroom and } \\
\text { practice place }\end{array}$ \\
\hline The second integration & $\begin{array}{l}\text { The integration of theory teaching and } \\
\text { practice guidance }\end{array}$ \\
\hline The third integration & $\begin{array}{l}\text { The integration of professional theory and } \\
\text { practical operation }\end{array}$ \\
\hline
\end{tabular}

\begin{tabular}{|l|l|}
\hline $\begin{array}{c}\text { The indexes of } \\
\text { integration }\end{array}$ & \multicolumn{1}{c|}{ The types of integration } \\
\hline The fourth integration & $\begin{array}{l}\text { The integration of equipment practical } \\
\text { operation and virtual training }\end{array}$ \\
\hline The fifth integration & $\begin{array}{l}\text { The integration of college training and } \\
\text { army actual combat }\end{array}$ \\
\hline
\end{tabular}

The teaching mode is close to the actual combat. "theory virtual equipment combat" teaching mode is not only the integration of theoretical teaching and practical teaching content, but also the integration of the knowledge, skills and teaching ability of teachers. At the same time, it also includes the integration of teaching places, college education and military practice. Starting from the cognitive law of students' skills, it realizes the organic integration of theory, virtual, practice and actual combat Integration.

\section{The basic conception of the innovation of "theory virtual equipment combat" integrated teaching mode of aircraft spares seal up for safekeeping technology course}

\subsection{Construct the training environment of "theory virtual equipment combat"}

The construction of "theory virtual equipment combat" teaching place is the basic guarantee condition for the reform of "theory virtual equipment combat" teaching mode. Its design requirements start from the teaching demand of "theory virtual equipment combat", fully consider the teaching characteristics of air material storage, aim at the position of students, and closely follow the actual situation of air material storage. "theory virtual equipment combat" training center integrates teaching, practical operation, drilling, disassembly, maintenance, deduction, virtual reality, role experience and other functions. At the same time, in the same space and at the same time, the theory and practice teaching are completed simultaneously, which embodies the concept of teaching, learning and practicing. The zero distance interaction between teachers and students can be realized through the information platform, so as to better realize the "integration of human and equipment" in aviation material storage. The construction of a central focus, multi-point radiation, omni-directional, three-dimensional network training center, to achieve the integration of teaching, testing, testing, assessment, practice, decision-making, command, scientific research and other functions of aircraft spares seal up for safekeeping.

\subsection{Construct the task-based "theory virtual equipment combat" teaching material system of aircraft spares seal up for safekeeping technology course}

The teaching of "theory virtual equipment combat" of aircraft spares seal up for safekeeping technology course should have teaching materials matching the major and planning. Traditional teaching materials generally 
emphasize the comprehensiveness and systematicness of theory, which can not meet the needs of "theory virtual equipment combat" teaching. According to the teaching objectives and tasks, all knowledge points should be decomposed into practical training tasks, and skills training should be carried out in a planned way to let students know what they are. Teachers explain the problems in students' practice with professional theoretical knowledge, so that students know why, so as to realize the organic combination of theory and practice. According to the teaching characteristics of aircraft spares seal up for safekeeping technology course, the original curriculum structure, system, content and teaching methods are reformed based on the concept, mode and method of vocational education, and the teachers are organized to compile the teaching material of theory and practice guided by project and driven by task. We should break through the traditional teaching materials, pay attention to the comprehensive and systematic curriculum system of theory, take the ability as the standard, take the guarantee practice as the main line, take the task driven as the main body, carry out the innovation and integration of the course content, make the necessary choice and combination of the content according to the requirements of the post and the needs of the students' personality development, and adjust the depth and breadth of the content appropriately.

\subsection{Building a double qualified "theory virtual equipment combat" teaching staff of aircraft spares seal up for safekeeping technology course}

The teaching of "theory virtual equipment combat" of aircraft spares seal up for safekeeping technology course needs excellent teachers. In order to implement the integration of theory and practice teaching, teachers are required to have not only solid professional theoretical foundation, but also more proficient practical skills, as well as the ability of teaching material analysis and process combination. Teachers are not only double qualified talents in the traditional sense, but also have the ability of innovation and comprehensive. Otherwise, it is difficult for the teaching scheme to be issued and the teaching process is difficult to control. It is difficult for teachers to respond to their demands and answer questions and understand them thoroughly. Strengthening the practical teaching environment is an effective way to realize the organic combination of theory and practice, teaching and production. The key to improve the quality of practical teaching is to have a excellent team of double qualified professional teachers

\subsection{Construct the objective "theory virtual equipment combat" teaching quality evaluation method of aircraft spares seal up for safekeeping technology course}

The teaching quality evaluation of "theory virtual equipment combat" reform of aircraft spares seal up for safekeeping technology course is based on the personnel training objectives and post requirements. The final scores of related core courses can be comprehensively evaluated by the assessment results of various skills training projects and theoretical examination scores according to the weight. To assess students' ability to solve practical problems, we should not only have qualified materials, advanced equipment and means, but also have scientific and standardized quality management and control. We should ensure the teaching quality evaluation system with full participation, all factors and the whole process. While highlighting the pertinence and application of talent training, students should have certain sustainable development ability and promote their all-round development. Process assessment and project task comprehensive assessment should be widely carried out, and various evaluation methods should be adopted as far as possible to ensure that the equipment teaching characteristics of taking skill training as the core and meeting the post demand as the ability goal are adhered to.

\subsection{Promoting the construction of "theory virtual equipment combat" practical teaching environment of aircraft spares seal up for safekeeping technology course}

The construction of "theory virtual equipment combat" teaching place of aircraft spares seal up for safekeeping technology course will break the boundary between the classroom and the practice room, truly realize "where to talk, what to see, where to practice", and effectively integrate teaching time and space, which is the perfect integration of theory and practice. The planned and constructed "theory virtual equipment combat" aircraft spares seal up for safekeeping training center makes full use of modern information technology and high-tech means, integrates various detection and maintenance platforms, so that students can experience their future roles. Through the actual combat environment, they can fully understand the process of aircraft spares seal up for safekeeping and master the key and difficult problems in various links of aircraft spares seal up for safekeeping.

\section{The teaching ideas of "theory virtual equipment combat" integrated teaching mode of aircraft spares seal up for safekeeping technology course}

The basic teaching ideas of "theory virtual equipment combat" integrated teaching mode of aircraft spares seal up for safekeeping technology course are as follows:

The first is to adhere to the post education and training objectives as the basis, based on the position of aircraft spares seal up for safekeeping technology course in the personnel training of aircraft spares management specialty and the characteristics of this technology, highlight the cultivation of application ability and organization management ability, and pay full attention to the organic combination of "teaching, learning and doing";

The second is to comply with the objective law that people understand and accept things. Teaching should be 
from shallow to deep, from easy to difficult, step by step, using real equipment, virtual simulation system and other means, starting from the structure and principle of equipment to the analysis of seal up for safekeeping method, and finally to the practical application;

Thirdly, the cultivation of innovation ability should be carried out in the teaching, and effective teaching methods should be adopted to guide students to think whether the existing technology can meet the requirements of sealing and how to improve it on the basis of mastering the theory and sealing technology;

Fourthly, focusing on the cultivation of students' ability, the teaching practice subjects are divided into several categories, such as accessories oil seal, engine oil seal, dry air seal, etc. The teaching of the first subject in each category is led by the teacher, while the teaching of other similar follow-up subjects is led by students. The students draw inferences from one instance according to the first subject, self-study, self-design, self-organization and implementation, and then evaluated by teachers. Modular teaching is adopted for each subject, and some modules are given to students, and the teaching mode is still in accordance with the mode of self-study, self-design, self-organization and implementation, and teacher evaluation;

Fifthly, practice is the only way to form the ability, so we should strengthen the practical practice of students' sealing skills and sealing organization and management ability, the implementation methods including group implementation, station rotation or phased implementation and so on.

\section{Conclusion}

The teaching mode of "theory virtual equipment combat" is a new teaching concept, its popularization and application will surely lead to a revolution in the teaching of aircraft spares seal up for safekeeping technology course. In the process of teaching reform of "theory virtual equipment combat", the aircraft spares seal up for safekeeping teachers will continue to change, their improvement of comprehensive quality will not only promote personal growth and progress, but also make their teaching ability achieve new breakthroughs. At the same time, the mode can promote the comprehensive ability and quality of the students, and can continuously meet the demand of modern war for aircraft spares seal up for safekeeping talents. Meanwhile, the ability and quality of the students such as hands-on ability, innovative thinking ability, comprehensive research ability, analysis and decision-making ability will also be comprehensively improved, which can better adapt to the requirements and long-term development in the future aircraft spares seal up for safekeeping post.

\section{Acknowledgment}

The authors declare that they have no conflict of interest. Informed consent was obtained from all individual participants included in the study.

\section{References}

1. Guo F, Wang D X, Liu C Y, et al, "Study the Teaching Mode of the Integration of Theory and Real Equipment ---- Take the Teaching Mode Reform of Aircraft Spares Sequestration Course as an Example". International Conference on Industrial Technology \& Management Science, 2015, pp.1873-1876.

2. Brown R H, "Theory of Combat: The Probability of Winning”. Operations Research, 1963, pp:418-425.

3. Shang J, "Research on New Sports Teaching Mode Based on Virtual Reality Technique". Applied Mechanics and Materials, 2014, pp.644-650:60396042 . 